\title{
Stochastic processes dominate during boreal bryophyte community assembly
}

\author{
Nicole J. FEnton ${ }^{1}$ and Yves Bergeron \\ Institut de Recherche sur les Forêts, Université du Québec en Abitibi-Témiscamingue, 445 Boulevard de l'Université, \\ Rouyn-Noranda, Québec J9X 4 E5 Canada
}

\begin{abstract}
Why are plant species found in certain locations and not in others? The study of community assembly rules has attempted to answer this question, and many studies articulate the historic dichotomy of deterministic (predictable niches) vs. stochastic (random or semirandom processes). The study of successional sequences to determine whether they converge, as would be expected by deterministic theory, or diverge, as stochastic theory would suggest, has been one method used to investigate this question. In this article we ask the question: Do similar boreal bryophyte communities develop in the similar habitat created by convergent succession after fires of different severities? Or do the stochastic processes generated by fires of different severity lead to different communities? Specifically we predict that deterministic structure will be more important for large forest-floor species than stochastic processes, and that the inverse will be true for small bryophyte species. We used multivariate regression trees and model selection to determine the relative weight of structure (forest structure, substrates, soil structure) and processes (fire severity) for two groups of bryophyte species sampled in 12 sites (seven high-severity and five low-severity fires). Contrary to our first hypothesis, processes were as important for large forest-floor bryophytes as for small pocket species. Fire severity, its interaction with the quality of available habitat, and its impact on the creation of biological legacies played dominant roles in determining community structure. In this study, sites with nearly identical forest structure, generated via convergent succession after high- and low-severity fire, were compared to see whether these sites supported similar bryophyte communities. While similar to some degree, both the large forest-floor species and the pocket species differed after high-severity fire compared to low-severity fire. This result suggests that the "how," or process of habitat generation, influences community composition in this system and that a snapshot of habitat conditions taken at only one point in time is insufficient to explain species distribution.
\end{abstract}

Key words: biological legacies; black spruce forest; deterministic habitat niche; founder effects; liverworts; mosses.

\section{INTRODUCTION}

The study of community assembly rules has been an area of significant interest, with many studies articulated around the historic dichotomy of deterministic vs. stochastic. Deterministic theory held that species are found in predictable realized niches (Hutchinson 1959), based on both their abiotic/habitat (e.g., temperature, precipitation) and biotic (competitiveness) limitations (Götzenberger et al. 2012). In contrast, stochastic theory suggests that species' presence within a community is unpredictable, and based on stochastic processes such as priority effects during species colonization (e.g., Trowbridge 2007, Fukami et al. 2010). In addition to the stochastic effects associated with dispersal and colonization, the differential presence of biological legacies (habitat or propagules) generated by or retained after

Manuscript received 6 November 2012; revised 25 March 2013; accepted 28 March 2013. Corresponding Editor: B. P. Wilcox.

${ }^{1}$ E-mail: nicole.fenton@uqat.ca disturbance may affect community assembly in a stochastic manner (e.g., Foster et al. 1998, Turner et al. 2003, Pharo and Lindenmayer 2009). Despite the fact that biological legacies are in fact habitat structures, and thus at a small spatial scale a deterministic factor, at a larger scale their presence, absence, and abundance may be associated with stochastic factors stemming from weather patterns. The unified neutral theory of biodiversity and biogeography proposed by Hubbell (2001), which integrates speciation and ecological neutrality into MacArthur and Wilson's theory, is an extreme example of stochastic theory.

One avenue for examining the relative importance of deterministic vs. stochastic processes in community assembly is the study of successional sequences (i.e., species replacement sequences over time). Successional sequences should converge under deterministic theory, as competition and habitat factors become dominant. However, successional sequences would be expected to diverge under stochastic theory as there has been a longer period of time during which random events 
associated with colonization order can accumulate within a site (e.g., McCune and Allen 1985, Lepš and Rejmánek 1991, Inouye and Tilman 1995, Samuels and Drake 1997, Fukami et al. 2005, Trowbridge 2007).

Boreal forests have been described as systems in which succession is generally absent, as the rapid return interval of large disturbances (stand-replacing fire in North America; Johnson 1992, Payette 1992) results in the selection of vascular plant species that tolerate a wide variety of habitat conditions, and that rapidly recolonize available space from underground rhizomes (e.g., Shafi and Yarranton 1973, Rowe 1983, Schimmel and Granström 1996). Consequently most species present before disturbance return almost immediately after disturbance, with the exception of a few short-lived early successional species such as grasses. Therefore the tree layer and the understory vascular layer were not historically seen to experience succession in the classical sense of species replacement. Bryophytes frequently dominate the understory and the species can be broadly split into large species growing across the forest floor and small species occupying discreet habitat patches (Frisvoll 1997, Økland et al. 2003). In contrast to the vascular plants, bryophytes do experience successional shifts postfire in the boreal forest (Black and Bliss 1978, Foster 1985). However, research over the last 20 years has shown that both the vascular plant and the bryophyte communities experience some successional shifts following disturbance (Foster 1985, Taylor et al. 1987, DeGrandpré et al. 1993, Fenton and Bergeron 2006). Furthermore, convergent succession is seen in some stands initiated by disturbances of different intensities (e.g., high- and low-severity fires) and with different initial colonizing tree species. In these systems the forest structure and the vascular plant communities converge on a typical old growth black spruce (Picea mariana (Mill.) B.S.P.) stand (Harper et al. 2005, Lecomte et al. 2005, Belleau et al. 2011; c.f. Taylor and Chen 2011) despite their different origins. This would suggest that deterministic processes, such as the realized niche (habitat structure and competition), are the dominant components of the assembly rules for this community. Stochastic processes appear to play little role, particularly in old growth forests, as would be predicted by traditional plant ecology theory (Lepš and Rejmánek 1991, Campetella et al. 2011).

In this article we ask the question: Do the similar habitats generated by convergent succession after fires of different severities support similar bryophyte communities? Or do the stochastic processes related to these different origins lead to different communities? Bryophytes are an interesting group as they influence many ecosystem functions in boreal forests and represent a significant proportion of the plant diversity (Fenton and Bergeron 2008, Turetsky et al. 2012). Despite the response of bryophytes to habitat structure (Fenton et al. 2003, Mills and MacDonald 2005), previous studies have suggested that stochastic processes, such as dispersal and establishment, may play a significant role in determining bryophyte community composition (e.g., Økland et al. 2003, Fenton and Bergeron 2008, Ellis and Ellis 2010). Furthermore the bryophyte community includes a diversity of life-forms, including large forest-floor mosses, peat mosses, and small pocket species (physically small species colonizing small pockets of specialized habitat; Frisvoll 1997, Økland et al. 2003). Large forest-floor species and peat mosses are generally believed to be structured by niche differentiation (light availability and moisture) and competition as they compete for space on the forest floor (Økland 1990, Slack 1990, Rydin 1997; but see Frego 1996). In contrast the smaller species are more dependent on the availability of pockets of habitat, and consequently stochastic dispersal, priority effects, and biological legacies may be more important in determining community structure (Slack 1990, Söderström and Herben 1997, Økland et al. 2003, Laaka-Lindberg et al. 2006, Fenton and Bergeron 2008). Therefore, we hypothesize that structure will be more important than process for large forest-floor species, and that in contrast stochastic processes (fire severity) will be more important than habitat structure for pocket species. The convergent succession of the habitat variables in this system makes time since fire a complex variable, as in addition to the deterministic habitat variables, it also incorporates time for stochastic or rare events to occur (Fenton and Bergeron 2008). Consequently time since fire is not treated explicitly in the hypotheses but is included in the analyses.

\section{Materials And Methods}

\section{Study area}

The study area is located within the Clay Belt of northeastern Ontario and northwestern Québec (Fig. 1). The northern portion is dominated by black sprucefeather moss (Pleurozium schreberi (Brid.) Mitt.) forests, and is particularly prone to paludification between fires, due to its poorly drained and clay dominated soil, low topographic relief, and moderately humid and cold climate $(889.9 \mathrm{~mm}$ of precipitation annually; annual mean temperature $0.7^{\circ} \mathrm{C}$; Environment Canada 2004). Large fires that kill aboveground vegetation are the dominant disturbance type. Between 1850 and 1920 the fire cycle was about 135 years, and it has since increased to about 398 years (Bergeron et al. 2004). Consequently the average age of the forests is in excess of 100 years.

\section{Sampling}

A chronosequence approach was used to address successional change. In order to ensure that the initial conditions were the same for all stands, sites were validated via comparison of slope and soil texture, stem analysis (dating and measurement of tree rings along the stem to determine growth patterns; Simard et al. 2007), and in situ analysis of the forest floor (analysis of macrofossils in the organic forest floor to determine 


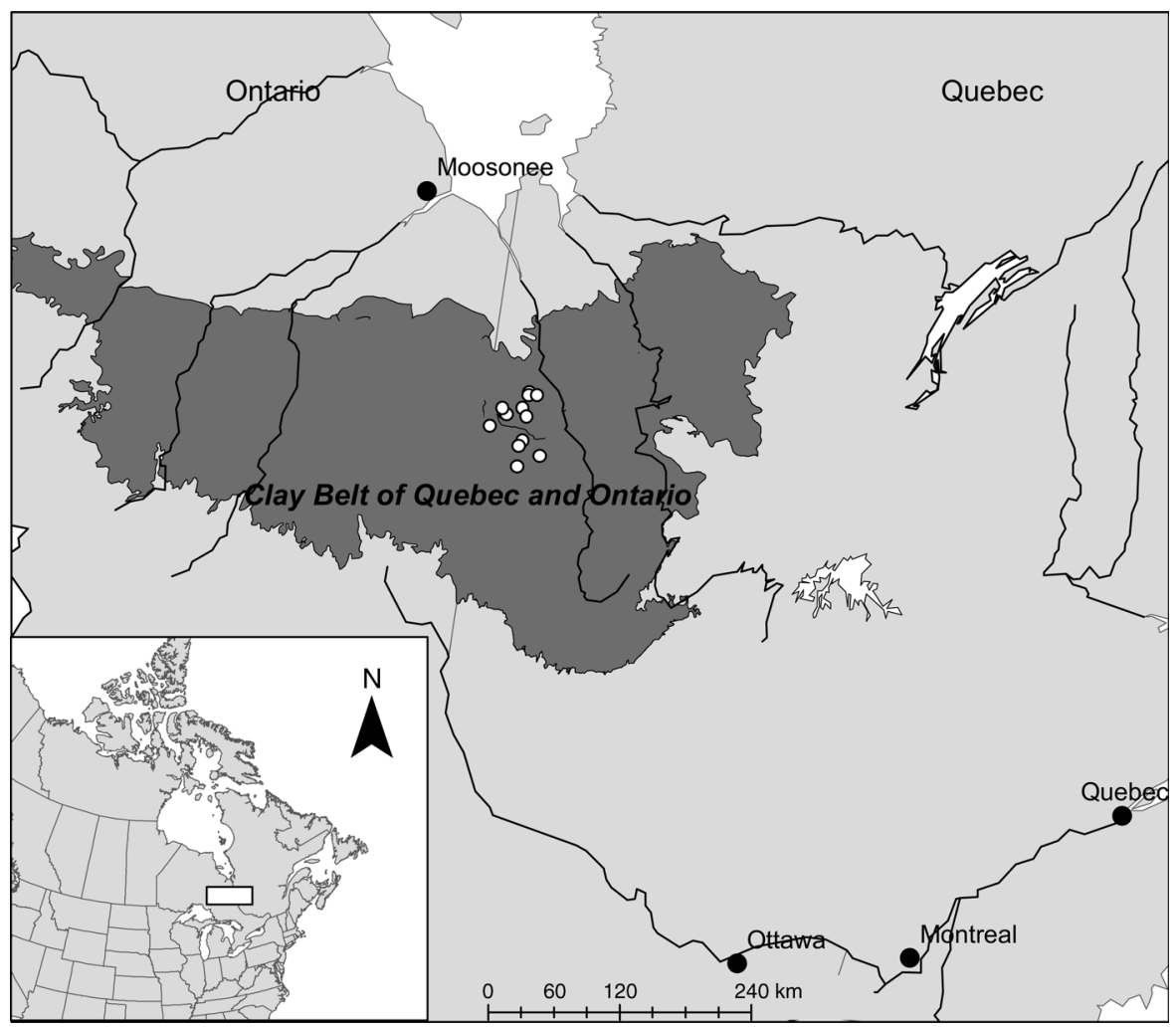

FIG. 1. The location of the Clay Belt within eastern North America and of the study sites within the Clay Belt.

successional changes in understory composition; Lecomte et al. 2006). Finally, a previous study indicated that older forests have escaped fire by chance, and are not permanent topographic escapes (Cyr et al. 2005).

Eighteen black spruce stands, ranging in age from 50 to 350 years since fire, were chosen based on a stand initiation map of the area (Bergeron et al. 2004). They were selected in the field based on: road proximity, the presence of a mild slope, and clay-dominated soil. Time since fire (TSF) was established by verification of stand initiation dates by dating basal cross sections of a few dominant trees (Simard et al. 2007). However, $C^{14}$ dating of charcoal particles obtained in some of the oldest stands ( $>200$ years TSF) suggests that the oldest trees were established considerably after a standreplacing fire. While these dates suggest that the stands are considerably older than first believed (by 300-1000 years), they did not alter the order or the groupings of the sites.

Sites were classified as originated after either high- or low-severity fire based on whether the most recent charcoal layer was within $5 \mathrm{~cm}$ of the mineral : organic interface evaluated in either soil trenches or soil pits. High-severity fire sites had a mean residual thickness of 1-3 cm while low-severity fires had a mean residual thickness of $7-50 \mathrm{~cm}$. The use of the $5-\mathrm{cm}$ cutoff is reasonable as Greene et al. (2007) have shown that this is approximately the limit at which the radical can reach the mineral soil during seed germination. Consequently there is a high success rate of seed germination, and a dense stand is developed. A more detailed description of the determination of fire severity at the sites is given by Lecomte et al. (2006).

During the summer of 2003 , five $100-\mathrm{m}^{2}$ plots were installed in each stand, each with four nested quadrats of $25 \mathrm{~m}^{2}$. The initial $100-\mathrm{m}^{2}$ plot was randomly placed at least $50 \mathrm{~m}$ from the nearest road, and subsequent quadrats were placed at least $10 \mathrm{~m}$ apart along a randomly chosen bearing. Within each $25-\mathrm{m}^{2}$ quadrat all bryophyte species and Cladina species (reindeer lichens) were identified and their percent cover was visually estimated. As large Cladina species occupy space on the forest floor in the same way as forest-floor bryophytes, they are included with the bryophytes for this study, for simplicity. Samples of all species that were not easy to identify were collected for identification in the laboratory with voucher specimens stored at the Universite du Québec en Abitibi-Témiscamingue. A series of habitat variables (both abiotic and biotic) affecting substrate availability and microclimate were measured in each 25 $\mathrm{m}^{2}$ quadrat in order to interpret the bryophyte pattern (Table 1).

Data from all 18 sites were analyzed to confirm the convergent succession in the habitat variables. Subsequently, when specifically addressing convergent species succession after high- and low-severity fires, 12 of the 18 
TABLE 1. Abiotic and biotic variables, classified as an indicator of structure or process, measured in order to interpret patterns in bryophyte species composition.

\begin{tabular}{|c|c|}
\hline Variable name & Description \\
\hline \multicolumn{2}{|l|}{ Forest structure/habitat } \\
\hline Organic layer thickness $(\mathrm{cm})$ & $\begin{array}{l}\text { depth from the moss surface to the organic-mineral interface, which is clearly } \\
\text { defined on the Clay Belt }\end{array}$ \\
\hline Percent coniferous canopy cover & percent canopy cover occupied by coniferous trees, measured on a densiometer \\
\hline Percent cover without canopy & $\begin{array}{l}\text { percentage of canopy that is not covered by coniferous or deciduous trees and is } \\
\text { therefore open to the sky }\end{array}$ \\
\hline $\begin{array}{l}\text { Percent cover of coarse woody debris, } \\
\text { decay class } 2\end{array}$ & $\begin{array}{l}\text { percentage of the forest floor covered by coarse woody debris }>5 \mathrm{~cm} \text { in diameter } \\
\text { decay class } 2 \text { (CWD2), bark loosening }\end{array}$ \\
\hline $\begin{array}{l}\text { Percent cover of coarse woody debris, } \\
\text { decay class } 3\end{array}$ & $\begin{array}{l}\text { percentage of the forest floor covered by coarse woody debris }>5 \mathrm{~cm} \text { in diameter } \\
\text { decay class } 3 \text { (CWD3), bark falling, softening of wood }\end{array}$ \\
\hline $\begin{array}{l}\text { Percent cover of coarse woody debris, } \\
\text { decay class } 4\end{array}$ & $\begin{array}{l}\text { percentage of the forest floor covered by coarse woody debris }>5 \mathrm{~cm} \text { in diameter } \\
\text { decay class } 4 \text { (CWD4), very soft, shape collapsed }\end{array}$ \\
\hline Percent cover peat pits & exposed peat and water holes formed in the organic layer \\
\hline Mean tree diameter $(\mathrm{cm})$ & mean diameter of all trees $>8 \mathrm{~cm}$ in the quadrat \\
\hline Live crown ratio black spruce & $\begin{array}{l}\text { mean percentage of black spruce stems with living foliage, measured as a visual } \\
\text { estimate }\end{array}$ \\
\hline Live crown ratio balsam fir & $\begin{array}{l}\text { mean percentage of balsam fir stems with living foliage, measured as a visual } \\
\text { estimate }\end{array}$ \\
\hline Percent cover of ericaceous species & $\begin{array}{l}\text { percentage of the forest floor covered by the canopy of ericaceous species, } \\
\text { primarily Rhododendron groenlandicum, Kalmia angustifolia }\end{array}$ \\
\hline \multicolumn{2}{|l|}{ Process } \\
\hline Fire severity & $\begin{array}{l}\text { severity of the last fire, binomial, with high-severity fires classified as } 1 \text { and low- } \\
\text { severity fires as } 0\end{array}$ \\
\hline Residual organic layer thickness $(\mathrm{cm})$ & $\begin{array}{l}\text { thickness of the organic layer between the most recent charcoal layer and the } \\
\text { mineral-organic interface: high-severity fires, } 1-3 \mathrm{~cm} \text { mean residual thickness; } \\
\text { low-severity fires, } 7-50 \mathrm{~cm} \text { residual thickness }\end{array}$ \\
\hline TSF (years) & time since fire, determined by dendrology or $\mathrm{C}^{14}$; see Materials and methods \\
\hline
\end{tabular}

Note: Classes of coarse woody debris decomposition were modified from Söderström (1987).

sites were included in order to compare only the sites with similar habitats, as indicated by the initial habitat analyses. Therefore all of the sites established after highseverity fire that were at least 200 years postfire (seven sites), and all of the low-severity fire sites (five sites) were included in the bryophyte community analyses.

\section{Analyses}

Convergent habitat variables.- Habitat variables were analyzed by principal component analysis (PCA) to confirm the convergent succession in the habitat variables. Specifically, habitat variables of the $25-\mathrm{m}^{2}$ quadrats after high-severity fire were analyzed with PCA and the low-severity fire quadrats were passively placed over the pattern generated by the high-severity plots $(N$ $=256$ high-severity quadrats in 13 sites and $N=98$ lowseverity quadrats in five sites). This technique permitted us to determine which part of the high-severity fire successional sequence the low-severity quadrats most resembled. CANOCO version 4.02 (ter Braak and Šmilauer 1998) with default settings was used for the PCA. While young (100-150 year time since fire) high- and low-severity sites differed in their structure, the low-severity sites of all ages completely overlapped with the older ( $>180$ years time since fire) high-severity sites (Appendix A). This confirmed the results in Lecomte et al. (2006), and the basic premise of our study, that the available habitat converges over time, and that the available habitat after low-severity fire was the same as in sites over 180 years after high-severity fire.
Bryophyte community composition.-The bryophyte community data were split into two groups, which were analyzed separately. Forest-floor bryophytes and pocket species (sensu Frisvoll 1997, Økland et al. 2003) represent two different life strategies within the bryophyte community. While forest-floor bryophytes grow over the forest floor competing for space, pocket species occupy small spatially and temporally distinct habitat patches that require regular dispersal to new habitat patches. As such they fit respectively into the perennial stayer or dominant (forest-floor species) and colonist and shuttle strategies (pocket species) of During (1992). The mechanisms driving these communities are not believed to be identical, and specific hypotheses for each group were made. Furthermore, the types of analyses possible for the two groups differ, as the pocket species are much less common and abundant, rarely having an abundance greater than trace (defined as covering less than $1 \%$ of the $25-\mathrm{m}^{2}$ quadrat). Therefore, many statistical analyses looking at individual pocket species, or pocket species communities, generally explain a very small amount of the variation. Consequently we adopted different analytic strategies for the two groups.

Forest-floor species.-Forest-floor species (feathermosses, peat mosses, and Cladina; for a complete list see Appendix B) data were analyzed by multivariate regression trees (MRT; De'ath 2002, Larsen and Speckman 2004). MRT permits the analysis of an entire community of species and multiple explanatory vari- 
ables within one model or tree (Larsen and Speckman 2004), and is a form of constrained clustering where the data are recursively partitioned to minimize the dissimilarity within the resulting groups using different levels of the explanatory variables. MRT is a robust method that makes no assumptions as to the form of the relationship between species and the explanatory variables. Trees are typically described by their fit, as the inverse of relative error (RE) and their predictive accuracy estimated via the cross-validated error (CVRE), which varies from 1 for poor prediction to close to zero for good prediction (De'ath 2002). In this study MRT was applied to the forest-floor species data set (19 species and 118 quadrats in 11 sites, seven high severity and four low severity; one low-severity site [N5 in Appendix A: Table A1] was eliminated as it was dominated by a different species and may have been subject to a different moisture regime), to determine whether variables associated with structure or process accounted for a larger proportion of the explained variance in the model, and whether quadrats in highand low-severity fires were discriminated. As such in relation with our hypotheses, if fire severity, or residual organic layer thickness accounted for significant proportions of the variability explained, stochastic process would be more important than deterministic structure.

The species data were normalized with a chord transformation (Borcard et al. 2011); sites were included as dummy variables to take into account the nested data; and the size of the tree was determined by examining the relationship between CVRE and the number of groups over 1000 iterations. Subsequently the average cover of the different bryophyte species and the environmental variables for each leaf (end group) were calculated. The amount of variation explained by the tree overall and by each branch were also determined.

Pocket species.-The species richness of different pocket species guilds was analyzed after high and lowseverity fire to determine the relative importance of structure and process for this group. Richness was analyzed rather than composition or a diversity index as almost all species had very low cover. Composition of the community was taken into account by analysis of the different guilds. Mosses (bryopsida or "true mosses"; Buck and Goffinet 2000) in this data set were primarily species occupying spatially and temporally discrete habitats most commonly found in forests (e.g., tree trunks or coarse woody debris, CWD). The liverworts (Hepatophyta), which were almost exclusively pocket species, were divided into "forest liverworts," which occurred in habitats primarily found in forests and "bog liverworts" that occurred in habitats primarily found in bogs. Classification of species into taxonomic/habitat guilds was based on Crum and Anderson (1981) for the mosses and Ley and Crowe (1999) for the liverworts, as well as personal observations. A species list is available in Appendix B.
The following questions were addressed through mixed-model analyses with model selection and model averaging (Burnham and Anderson 2002): (1) Is species richness of the different guilds the same after high- and low-severity fire? (2) Does fire severity (processes) or habitat structures (CWD of different decay states, exposed peat, and exposed mineral soil; see Table 1) best explain this species richness? CWD and exposed peat are the two main substrates for pocket species in these forest types, and have been shown to be important drivers in species richness for these groups (Fenton and Bergeron 2008). While the creation of these habitats may seem stochastic on small spatial or temporal scales, their generation within the forest stand over time is predictable (Lecomte et al. 2005). Time since fire in this habitat is a complex variable, as it incorporates many of the habitat changes seen via succession but also time for stochastic or rare events to occur (Fenton and Bergeron 2008). Because of this dual role, and subsequent correlation with the habitat variables, it could not be used as a process variable in the analyses for pocket species.

We used mixed models to analyze the data because of the structured (nested) data. Mixed models permit the separation of the variability associated with the spatial factors (site) and the factors of interest (structure and process; Pinheiro and Bates 2000). Here, we considered the site variable as a random effect, as the data were agglomerated to the plot level (i.e., the richness for each plot, including the four nested quadrats, was calculated). Consequently the $N$ for each model was 60 plots, nested in seven high-severity sites and five low-severity sites. Each model represented a biological hypothesis, to test the importance of fire severity, and exposed peat and CWD abundance in determining the species richness of the three groups (Table 2). Interactions were also included in the set of models, along with a null model, which represents the effect of the structured data alone. We contrasted these different hypotheses based on Akaike's information criteria corrected for small sample size $\left(\mathrm{AIC}_{\mathrm{c}}\right)$. Model selection is better suited to hypothesis testing in observational studies compared to traditional variable selection as it better incorporates both Occam's razor (simplicity and parsimony) and uncertainty in model building (Burnham and Anderson 2002, Mazerolle 2006). Species richness was squareroot-transformed for normality. The fit and residuals of the most complex models (global models) were evaluated. We ranked models by their $\mathrm{AIC}_{\mathrm{c}}$, and computed associated measures (delta $\mathrm{AIC}_{\mathrm{c}}$, Akaike weights) as well as model-averaged estimates for the variables in the models with a delta $\mathrm{AIC}_{\mathrm{c}}$ less than four, using the $\mathrm{AIC}_{\mathrm{c}}$ modavg package (Mazerolle 2012). In order to illustrate the effect of each explanatory model, the model predicted values of guild richness was calculated using the modavgpred function of the $\mathrm{AIC}_{\mathrm{c}}$ modavg package and subsequently plotted against values of the explanatory variables. All analyses were completed using $\mathrm{R}$ version 2.15.0 (R Development Core Team 2012). 
TABLE 2. Models, by data set, parameters included, biological hypothesis, and the number of parameters estimated ( $K$; includes random effects).

\begin{tabular}{|c|c|c|c|}
\hline Data set & Model & Biological hypotheses & $K$ \\
\hline $\begin{array}{c}\text { Mosses + bog } \\
\text { liverworts }\end{array}$ & 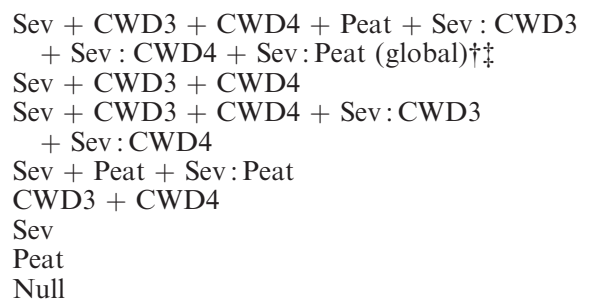 & $\begin{array}{l}\text { process, peat structure and interaction with process } \\
\text { deadwood structure } \\
\text { process } \\
\text { peat structure } \\
\text { nested data structure alone }\end{array}$ & $\begin{array}{l}6 \\
5 \\
4 \\
4 \\
3\end{array}$ \\
\hline $\begin{array}{l}\text { Forest } \\
\text { liverworts }\end{array}$ & $\begin{array}{l}\text { Sev }+ \text { CWDTot }+ \text { Peat }+ \text { Sev: CWDTot } \\
\quad+\text { Sev:Peat }(\text { global }) \S \\
\text { Sev }+ \text { CWDTot }+ \text { Peat } \\
\text { Sev + Sev:Peat } \\
\text { Sev + Sev:CWDTot } \\
\text { Sev } \\
\text { CWDTot } \\
\text { Peat } \\
\text { Null }\end{array}$ & $\begin{array}{l}\text { process, structure, and the interaction } \\
\text { process and structure, no interaction } \\
\text { process, peat structure, and interaction with process } \\
\text { process, deadwood structure, and interaction with process } \\
\text { process } \\
\text { deadwood structure } \\
\text { peat structure } \\
\text { nested data structure alone }\end{array}$ & $\begin{array}{l}6 \\
5 \\
5 \\
4 \\
4 \\
4 \\
3\end{array}$ \\
\hline
\end{tabular}

Notes: "Sev" refers to fire severity; "Peat" refers to peat abundance. See Table 1 for explanations of coarse woody debris (CWD) classes.

$\dagger$ A "+" indicates that both parameters were included in the model.

\$ A ":" indicates that the interaction between the two parameters was included in the model.

$\S$ In the forest liverwort model, CWD3 and CWD4 were combined as CWDTot. For mosses and bog liverworts this simplification resulted in considerably poorer models, so the original data were maintained.

\section{RESULTS \\ Forest-floor species}

The best model was the five-split, six-group model that explained $27 \%$ of the variation within the data set. The first split was based on time since fire (Fig. 2; 8.9\%), splitting the oldest sites (high and low severity) from the old high-severity sites and the young-old low-severity sites. The second level splits, representing over $10 \%$ of the variability were based on residual organic layer thickness. Finally, quadrats from low-severity fires were found in only two groups (groups 3 and 5), while quadrats from high-severity fires were found in five groups.

Species composition varied among the groups (Table 3) with a higher percent cover of Sphagnum fuscum and Cladina stellaris in both low-severity groups (groups 3 and 5). Other species varied among the groups shifting with time since high-severity fire. Explanatory variables also varied among the groups with minor but clear shifts in groups with time since fire, except for three of the four low-severity sites that were grouped together despite their age range of 50-275 years after fire (Table 4). Finally, while all but one site was grouped in the same leaf, the dummy site variables were not selected, indicating that the spatial structure of the data was not the primary driver of the species pattern.

\section{Pocket species}

For all three data sets, the relationship between the predictions based on the global model and the observed values were linearly correlated (Fig. 3; Spearman's rho, mosses, 0.39; forest liverworts, 0.46; bog liverworts, 0.42). However, for both the mosses and the forest liverworts (Table 5) the null model ranked highly among the candidate models. Indeed, the "best" model for mosses (Sev + Peat + Sev: peat interaction) was only 1.03 times more parsimonious than the null model (evidence ratio, 0.31/0.30). Similarly, the Sev model for forest liverworts was only 1.65 times better than the null model $(0.33 / 0.20)$. Consequently there is weak evidence for an effect of any variable for these two data sets. In the case of the bog liverworts, two models were clearly better than the null model, the model including both decomposition states of CWD and their interactions with severity, and the global model.

However, if the null models are excluded, the modelaveraged estimates of the coefficients for the different parameters indicate that severity and its interactions with habitat factors had the greatest impact on all three data sets (Table 5, Figs. 4-6). For the forest liverworts, species richness was higher after high-severity fires, (coefficient greater than 0.1 and the $95 \%$ confidence interval did not contain zero). As can be seen in Fig. 4, the slopes are small for both CWD and peat, and there is little difference in slope between high- and low-severity fires; therefore there is little interaction between severity and habitat.

For mosses, both severity and the interaction between severity and peat were greater than $|0.1|$, and only the interaction between peat and severity excluded 0 from the $95 \%$ confidence interval (Table 6, Fig. 6). This interaction results in higher moss richness at a given abundance of peat after low-severity fires. Similarly for 


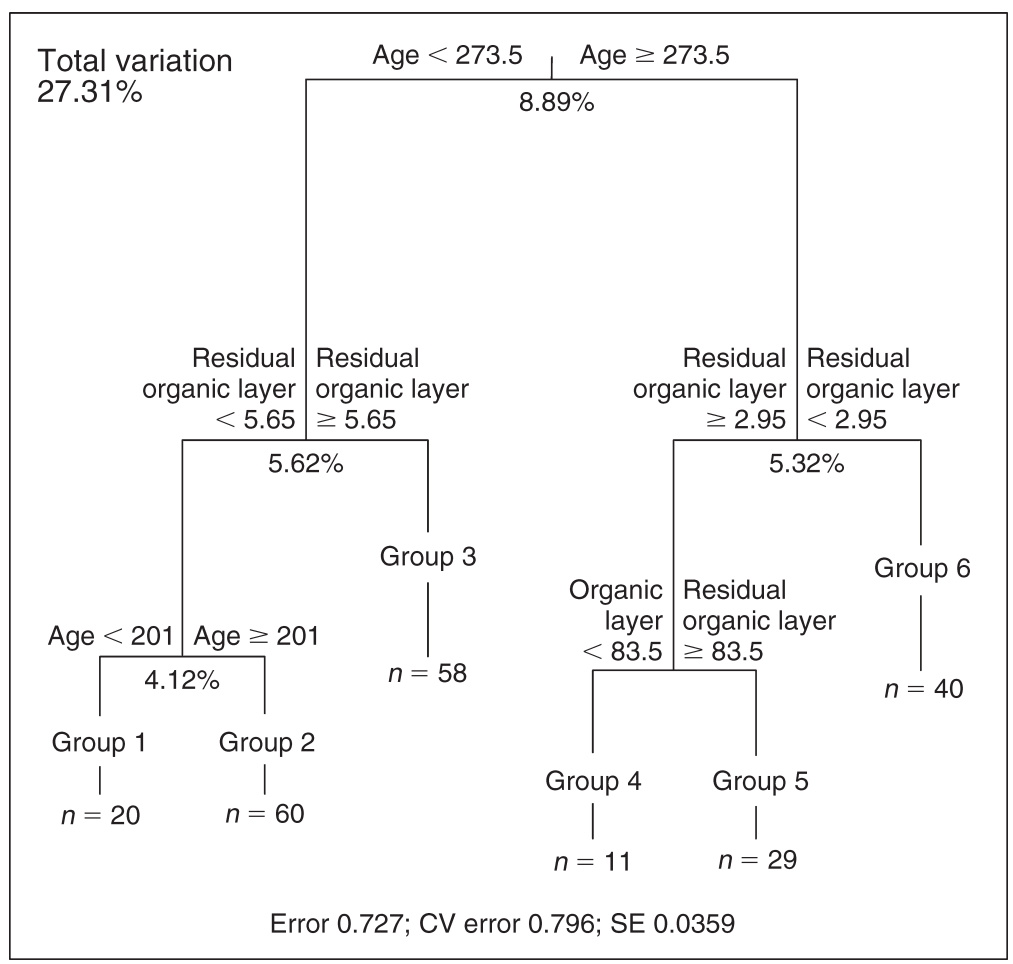

FIG. 2. Multivariate regression tree (MRT) of forest-floor species. The five-split, six-group model was the best model as selected by parsimony and cross-validated error (CVRE). Factors generating the split with their mean amounts are listed at each split. The amount of variation explained by the entire tree is the inverse of the error, in this case $27.31 \%$. This total is decomposed into the percentage explained by each split. The CV error indicates the potential for the unsuccessful classification of additional samples (i.e., $21 \%$ chance of successful classification). Each leaf is assigned a group number (indicated beneath the leaf on the graph) and the number of plots within each group or "leaf" is indicated.

the coefficients of bog liverworts (Table 6, Fig. 6), severity, and the interactions between severity and peat, CWD3 and CWD4 were greater than $|0.1|$. The coefficient for severity alone does not exclude 0 ; however the interactions between severity and CWD3 and CWD4 do exclude 0. As a result, as seen in Fig. 6, there is a substantial difference in slope between high- and low- severity fires resulting in differences in bog liverwort species richness after high and low-severity fires for a given amount of habitat. Interestingly after high-severity fire, bog liverwort richness increases with CWD3 abundance while it decreases with CWD3 abundance after low-severity fire. The inverse is true for CWD4, and to a lesser degree peat.

TABLE 3. Species composition of the groups determined by multivariate regression tree (MRT).

\begin{tabular}{|c|c|c|c|c|c|c|}
\hline Group & 1 & 2 & 3 & 4 & 5 & 6 \\
\hline Pleurozium schreberi & 45.5 & 31.7 & 45.6 & 14.1 & 27.9 & 18.5 \\
\hline Hylocomium splendens & 0.7 & 2.8 & 0.7 & 0.1 & 0.1 & 4.8 \\
\hline Ptilium crista-castrensis & 1.0 & 2.1 & 2.2 & 0.05 & 0.02 & 1.7 \\
\hline Ptillidium ciliare & 12.0 & 7.1 & 5.3 & 5.1 & 6.4 & 4.2 \\
\hline Polytrichum commune & 0.1 & 0.7 & 0.2 & 3.3 & 0.2 & 0.4 \\
\hline Sphagnum girgensohnii & 0.1 & 1.0 & 3.4 & 0.1 & 0.1 & 1.5 \\
\hline Sphagnum capillifolium & 12.3 & 7.6 & 17.6 & 0.1 & 9.8 & 7.1 \\
\hline Sphagnum russowii & 0.8 & 29.3 & 2.0 & 0.1 & 2.6 & 11.5 \\
\hline Sphagnum rubellum & 9.5 & 8.2 & 1.2 & 0.9 & 0.7 & 7.1 \\
\hline Sphagnum magellanicum & 0.1 & 1.2 & 0.5 & 3.7 & 0.8 & 17.9 \\
\hline Sphagnum fallax (sensu lato) & 0.8 & 5.4 & 2.9 & 58.6 & 16.2 & 13.8 \\
\hline Sphagnum warnstorfii & 0.1 & 0.1 & 0.1 & 0.1 & 0.1 & 0.3 \\
\hline Sphagnum wulfianum & 0.5 & 0.1 & 0.1 & 0.1 & 0.1 & 5.3 \\
\hline Sphagnum fuscum & 0.1 & 0.1 & 6.9 & 3.3 & 20.0 & 2.0 \\
\hline Cladina rangiferina & 10.4 & 0.8 & 3.4 & 6.9 & 9.3 & 1.2 \\
\hline Cladina mitis & 0.25 & 0.1 & 0.1 & 0.1 & 0.02 & 0.1 \\
\hline Cladina stellaris & 0.1 & 0.1 & 0.8 & 0.05 & 0.4 & 0.1 \\
\hline
\end{tabular}

Note: The mean percent cover of each species for each group is listed. 
TABLE 4. Environmental variables of the groups determined by multivariate regression tree (MRT).

\begin{tabular}{lrrrrrr}
\hline \hline \multicolumn{1}{c}{ Group } & 1 & 2 & 3 & 4 & 5 & 6 \\
\hline Mean TSF (yr) & 182 & 700 & 200 & 2000 & 1000 & 1500 \\
Severity & 1 & 1 & 0 & 1 & 0.3 & 1 \\
Exposed peat (\%) & 1.9 & 2.1 & 0.5 & 2.9 & 1.1 & 5.5 \\
CWD2 (\%) & 7.0 & 10.8 & 1.5 & 0.0 & 0.7 & 1.8 \\
CWD3 (\%) & 15.0 & 10.2 & 4.3 & 10.9 & 5.0 & 15.3 \\
CWD4 (\%) & 9.1 & 5.6 & 3.0 & 4.2 & 4.6 & 7.5 \\
Ericaceous shrubs (\%) & 57.9 & 67.3 & 66.8 & 75.0 & 78.6 & 56.3 \\
Organic layer thickness (cm) & 31.0 & 52.3 & 51.8 & 51.5 & 146.0 & 67.9 \\
Residual organic layer thickness (cm) & 2.0 & 2.7 & 24.9 & 3.2 & 70.0 & 2.7 \\
Open canopy (\%) & 57.4 & 65.6 & 64.7 & 72.6 & 78.1 & 70.4 \\
Coniferous canopy (\%) & 42.6 & 36.4 & 34.9 & 27.5 & 21.9 & 29.3 \\
Black spruce live crown ratio (\%) & 37.8 & 39.5 & 44.2 & 17.7 & 20.7 & 38.8 \\
Balsam fir live crown ratio (\%) & 1.5 & 9.2 & 0 & 0 & 0 & 5.9 \\
Mean tree diameter at breast height (cm) & 14.6 & 13.3 & 11.5 & 8.7 & 7.8 & 12.8 \\
\hline
\end{tabular}

Notes: The mean value for each group is given. See Table 1 for explanation of abbreviations.

$\dagger$ A value of 1 indicates that all of the quadrats were high severity while a value of 0 indicates that all of the quadrats were low severity. Fractions indicate the proportion of quadrats in high- and low-severity fires.

\section{DisCUSSION}

In this study sites with nearly identical forest structures, generated via convergent succession after high- and low-severity fire, were compared to see whether these sites supported similar bryophyte communities. While similar to some degree, both the large forest-floor species and the pocket species differed after high- compared to low-severity fire. This result suggests that the "how," or process of habitat generation, influences community composition in this system and that a static portrait of habitat conditions taken at one time is not sufficient to explain species distribution. As in other systems where deterministic effects are not sufficient to predict species composition (e.g., Frego 1996, Pharo and Vitt 2000), biological legacies left by the preceding disturbance event and subsequent founder or establishment history result in founder effects (Herben 1995 ) and may be the explanation for this pattern.

\section{Biological legacies}

The different biological legacies (Foster et al. 1998, Turner et al. 2003, Pharo and Lindenmayer 2009) left by the two types of fires resulted in different colonization patterns. After low-severity fire, the remaining layer of organic material (Lecomte et al. 2006) may have been primarily composed of partially consumed hummocks, as both observational studies (Benscoter and Wieder 2003, Shetler et al. 2008) and in situ macrofossil analysis (Benscoter et al. 2005, Benscoter and Vitt 2008) have demonstrated that there is greater combustion of hollows and lawns than hummocks. Furthermore the results of Simard et al. (2007) and Greene et al. (2007) indicate that this thick remnant organic layer suppresses tree regeneration resulting in an open stand with fewer and smaller trees than after high-severity fire.

This biological legacy (remnant organic layer) and its effect on tree regeneration profoundly influenced bryo- phyte community composition. After low-severity fire the initial environment consisting of a relatively thick layer of organic material primarily composed of hummock peat mosses provided a good environment for rapid sphagnum recruitment via dispersal from unburned zones (or true moss facilitators followed by peat mosses; see Robert et al. 1999 and Benscoter 2006). Alternatively, the prefire species could have resprouted postfire from surviving meristems within the hummock (Clymo and Duckett 1986, Benscoter et al. 2005), or from within unburned patches (Hylander and Johnson 2010). This would explain the higher cover of Pleurozium schreberi and hummock peat mosses (particularly Sphagnum capillifolium and S. fuscum; Table 3), species that typically grow in drier, thicker areas within peatlands (Heinselman 1963, Gignac 1992). In contrast after high-severity fire, the dry burned humus layer or exposed mineral soil provided no "fast track" for peat moss establishment, and after canopy closure feather mosses were able to establish and dominate the forest floor (Foster 1985, Taylor et al. 1987, Fenton and Bergeron 2006).

Similarly, the conditions created by the biological legacies and the resultant forest stand affected the suitability of the available substrates for pocket species. Low-severity sites do not go through the dense developmental stage that high-severity fire sites do (mature forest stage 50-200 years postfire; Simard et al. 2007). Consequently CWD generated in low-severity sites are exposed to a less humid environment for part of their development than CWD generated in high-severity sites. As a result CWD in low-severity sites may have been a less suitable substrate for forest liverworts than CWD in high-severity sites, or in the case of bog liverworts, CWD of a higher decomposition class (and therefore more humid) was needed to satisfy habitat requirements. Similarly, the loss of epixylic liverworts in 
managed forests is partially attributed to lower humidity (Söderström 1988), and a difference in vascular plant colonization patterns of logs after harvest and wildfire may have been driven by differences in the logs themselves (Lee and Sturgess 2001, Schmalholz et al. 2011).

Legacies after low-severity fire may have influenced pocket species via a second mechanism. Trees grow to larger sizes when established in the mineral soil, compared to the organic layer (Simard et al. 2007). These larger trees generate larger diameter CWD that may have offered a larger target for spores and diaspores, both spatially (larger surface area) and temporally (slower decomposition and slower overgrowth; Dynesius et al. 2010). This could have resulted in richer pocket species communities. Similarly Browning et al. (2010) found that forest structure and stochastic processes had a greater impact on the successional pattern of bryophytes in wet eucalypt forests than substrate availability.

\section{Founder effect}

Several studies have shown that the order in which species arrive in a community influences the community pattern (e.g., McCune and Allen 1984, Fastie 1995, Fukami et al. 2005, Trowbridge 2007), in many cases resulting in a form of preemptive competition (Rydin 1997) where the occupation of the available space by established species prevents better competitors from establishing (although within a species see Cronberg 2002 for the opposite pattern). In the low-severity sites this seems to be occurring as this community seems remarkably stable for several hundred years, as all the low-severity sites, except one, grouped together. Furthermore, lower hummock and hollow species (e.g., $S$. magellanicum, S. fallax (senso lato)) that are typically considered to be better competitors are less abundant after low-severity fire, compared to high-severity fire sites with similar habitat.

\section{Vascular plants vs. bryophytes}

In this study, bryophyte communities after high- and low-severity fire were not the same. This is in contrast to the vascular plant communities that experienced convergent succession (Lecomte et al. 2005). In the coniferous boreal forest, most vascular plants have typically been found to be generalists, capable of rapidly regenerating after disturbances via either in situ or ex situ propagules (Shafi and Yarranton 1973, Schimmel and Granström 1996, Jonsson and Esseen 1998, Rydgren et al. 1998). The boreal bryophyte community is in contrast to this, and studies that have attempted to explain bryophyte community composition have typically been only partially successful, as the weak relationships between composition and habitat variables in most studies attest (e.g., Pharo and Vitt 2000, Økland et al. 2003, Fenton and Bergeron 2006, Evans et al. 2012). Perhaps the smaller size of sexual and asexual
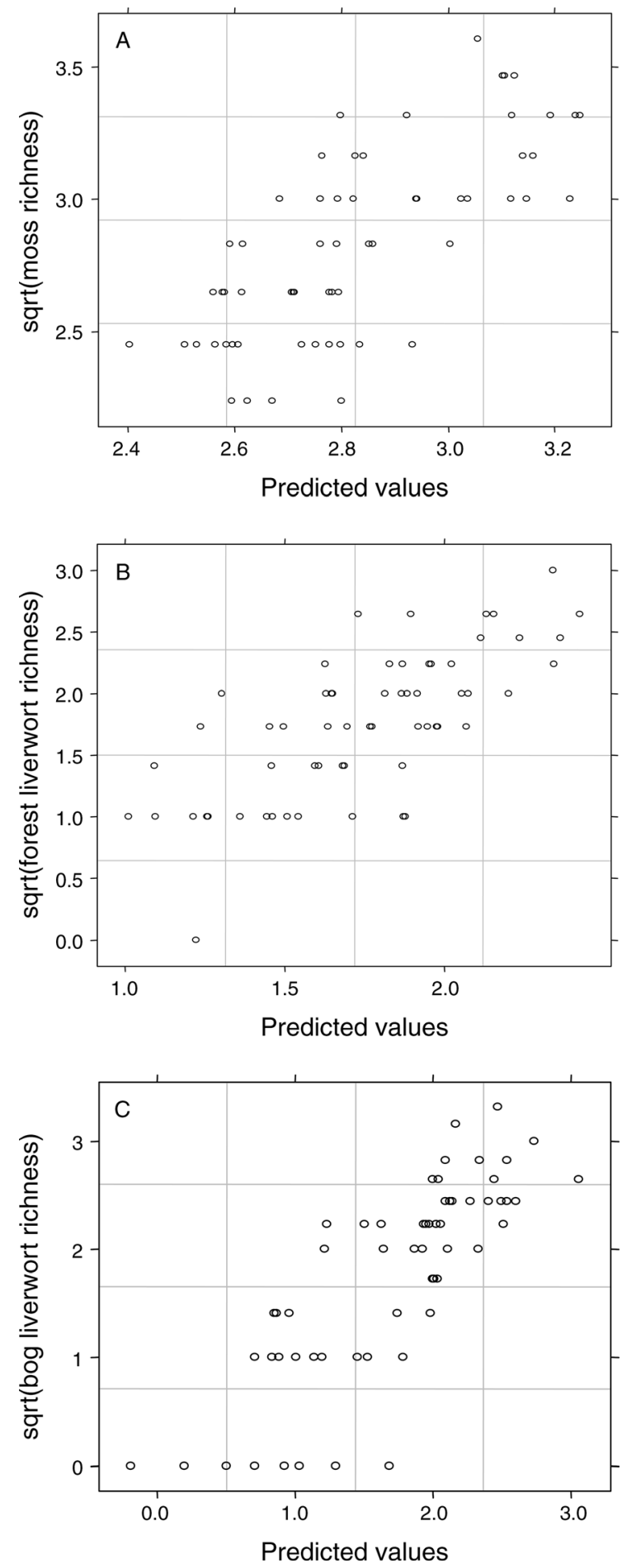

FIG. 3. Observed vs. predicted values for the global model of (A) mosses, (B) forest liverworts, and (C) bog liverworts. Note that the $x$ - and $y$-axes are not identical in the three graphs and that species richness is square-root-transformed. 
TABLE 5. Model selection results for the species richness of mosses, forest liverworts, and bog liverworts.

\begin{tabular}{|c|c|c|c|c|c|c|}
\hline Data set & Model & Log-likelihood & $K$ & $\mathrm{AIC}_{\mathrm{c}}$ & $\Delta \mathrm{AIC}_{\mathrm{c}}$ & $w_{i}$ \\
\hline Mosses & $\begin{array}{l}\text { Sev }+ \text { Peat }+ \text { Sev: Peat } \\
\text { Null } \\
\text { Sev } \\
\text { Peat }\end{array}$ & $\begin{array}{l}-16.04 \\
-19.66 \\
-18.29 \\
-19.40\end{array}$ & $\begin{array}{l}6 \\
3 \\
4 \\
4\end{array}$ & $\begin{array}{l}45.66 \\
45.75 \\
46.57 \\
47.52\end{array}$ & $\begin{array}{l}0.00 \\
0.09 \\
0.91 \\
1.86\end{array}$ & $\begin{array}{l}0.31 \\
0.30 \\
0.20 \\
0.12\end{array}$ \\
\hline Forest liverworts & $\begin{array}{l}\text { Sev } \\
\text { Null } \\
\text { Sev }+ \text { CWDTot }+ \text { Sev }: \text { CWDTot } \\
\text { Sev }+ \text { Peat }+ \text { Sev }: \text { Peat } \\
\text { Peat } \\
\text { CWDTot }\end{array}$ & $\begin{array}{l}-46.04 \\
-47.68 \\
-45.54 \\
-46.03 \\
-47.31 \\
-47.60\end{array}$ & $\begin{array}{l}4 \\
3 \\
5 \\
5 \\
4 \\
4\end{array}$ & $\begin{array}{l}100.80 \\
101.79 \\
102.20 \\
103.18 \\
103.35 \\
103.94\end{array}$ & $\begin{array}{l}0 \\
0.99 \\
1.40 \\
2.38 \\
2.55 \\
3.14\end{array}$ & $\begin{array}{l}0.33 \\
0.20 \\
0.16 \\
0.10 \\
0.09 \\
0.07\end{array}$ \\
\hline Bog liverworts & $\begin{array}{l}\text { Sev + CWD + Sev: CWD } \uparrow \\
\text { Global } \\
\text { Null } \\
\text { Peat } \\
\text { Sev }\end{array}$ & $\begin{array}{l}-68.39 \\
-66.60 \\
-75.69 \\
-74.80 \\
-75.19\end{array}$ & $\begin{array}{r}8 \\
10 \\
3 \\
4 \\
4\end{array}$ & $\begin{array}{l}155.59 \\
157.70 \\
157.81 \\
158.32 \\
159.11\end{array}$ & $\begin{array}{l}0.00 \\
2.10 \\
2.22 \\
2.73 \\
3.52\end{array}$ & $\begin{array}{l}0.44 \\
0.15 \\
0.14 \\
0.11 \\
0.08\end{array}$ \\
\hline
\end{tabular}

Notes: Species richness was modeled as a function of fire severity (process) and habitat availability (exposed peat and well decomposed CWD; i.e., structure). Only models with $\triangle \mathrm{AIC}_{\mathrm{c}}<4$ are presented, with the number of parameters included $(K)$, the second-order Akaike information criterion $\left(\mathrm{AIC}_{\mathrm{c}}\right)$, the distance from the best model $\left(\Delta \mathrm{AIC}_{\mathrm{c}}\right)$, and Akaike weight $\left(w_{i}\right)$.

$\uparrow$ The full model description was: CWD3 + CWD4 + Sev : CWD3 + Sev: CWD4.

propagules in bryophytes compared to vascular plants, with fewer resources attributed to propagules to ensure their success (During 1992), results in an inherently more stochastic establishment process. However, the better dispersal capacity of small spores compared to larger seeds may overcome this limitation.

\section{Conclusion}

The results of this study suggest that, in boreal bryophyte communities, assembly is driven more by processes rather than deterministic habitat characteristics. This conclusion supports the growing body of evidence that indicates that stochastic processes play a fundamental role in dictating community assembly.
Consequently models of species distribution based solely on habitat may in many cases be in fact poor facsimiles of reality (Huntley et al. 2010). Similarly the implications for restoration ecology and conservation biology in general, of this and other studies highlighting the important role of biological legacies, establishment history, and other stochastic elements in community assembly, are significant. These results indicate that both the coarse filter approach to conservation and the "build it and they will come" approach to restoration is not guaranteed to succeed as subtle processes dictate substrate suitability and the order of species establishment may ultimately determine species composition. As such, attention needs to be paid to conserve or create not

TABLE 6. Model-averaged estimate for the coefficients of the parameters in the models, including the unconditional standard error and the lower and upper $95 \%$ confidence interval obtained from multimodel inference explaining species richness in mosses, forest liverworts, and bog liverworts.

\begin{tabular}{clcccr}
\hline \hline \multicolumn{1}{c}{ Data set } & Parameter & Estimate & SE & Lower CI & Upper CI \\
\hline Mosses & Sev & 0.17 & 0.13 & -0.09 & 0.43 \\
& Peat & 0.01 & 0.02 & -0.02 & 0.04 \\
Fov : Peat & -0.2 & 0.08 & -0.37 & -0.04 \\
& Sev & 0.4 & 0.21 & -0.01 & 0.81 \\
& Peat & 0.02 & 0.03 & -0.03 & 0.07 \\
& CWDTot & 0 & 0.01 & -0.01 & 0.02 \\
Bog liverworts & Sev : Peat & -0.05 & 0.12 & -0.28 & 0.18 \\
& Sev : CWDTot & -0.01 & 0.01 & -0.01 & 0.03 \\
& Sev & 0.4 & 0.39 & -0.37 & 1.17 \\
& Peat & 0.06 & 0.04 & -0.03 & 0.14 \\
& CWD3 & -0.02 & 0.02 & -0.06 & 0.01 \\
& CWD4 & 0.04 & 0.04 & -0.03 & 0.11 \\
& Sev : CWD3 & 0.12 & 0.03 & 0.05 & 0.19 \\
& Sev : CWD4 & -0.2 & 0.08 & -0.35 & -0.05 \\
& Sev : Peat & -0.23 & 0.21 & -0.63 & 0.18
\end{tabular}

Notes: Parameters in italics do not include zero in the $95 \%$ confidence interval. See Tables 1 and 2 for explanations of abbreviations. 

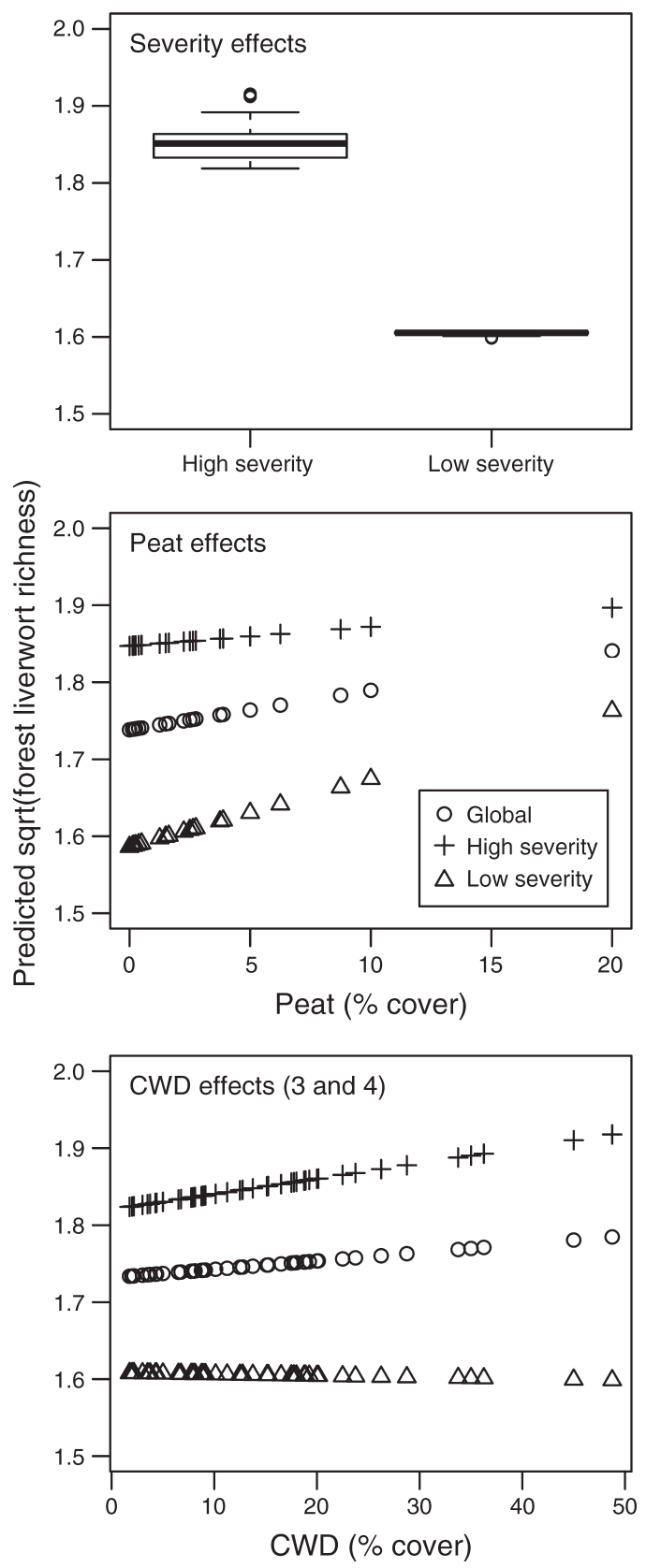

FIG. 4. Relationships between fire severity, peat abundance, and coarse woody debris (CWD3 and CWD4; see Table 1) abundance and predicted forest liverwort richness. For example, the models predict high richness after high-severity fire compared to that after low-severity fire. For peat and CWD abundance, the interaction between habitat abundance and fire severity is also illustrated. The horizontal line of the boxplot indicates the median, while the bottom and the top of the box indicate the 25 th and the 75 th percentiles. The whiskers indicate 2 SD. Points above or below 2 SD are indicated by dots. Some boxplots are very compact, appearing as lines. The global relationship (regardless of fire severity) is indicated by circles; the relationship with high-severity fires is indicated by crosses, and that with low-severity fire by triangles. only the structures but also the processes. Results from some large scale experiments in Fennoscandia have been only partially successful (e.g., de Chantal et al. 2009, Kouki et al. 2012), particularly in the treatments that did not mimic processes as closely (e.g., partial cut vs. prescribed fire for deadwood generation; Toivanen and Kotiaho 2010). Similarly, studies that have shown similar bryophyte communities in regenerating stands after forest management and old growth stands have all stressed the importance of biological legacies left by the forest management treatments (Lõhmus and Lõhmus 2008, Pharo and Lindenmayer 2009, Madžule et al. 2012). Therefore when considering the use of silviculture to create old growth attributes (Bauhus et al. 2009), special attention should be paid to not only the presence of a structure, but of its generation.

ACKNOWLEDGMENTS

Catherine Beland and Élise Vincent provided valuable field assistance. Discussions with Nicolas Lecomte and Sonia Légaré greatly enhanced the article. Bruce Bagnell provided valuable support during Sphagnum identification. Linda Ley verified the identifications. The comments of two anonymous reviewers greatly improved a previous version of the manuscript. Funding for this project was provided by the UQAT-UQAM National Science and Engineering Research Council Industrial Chair (NSERC), an NSERC scholarship awarded to N. J. Fenton,

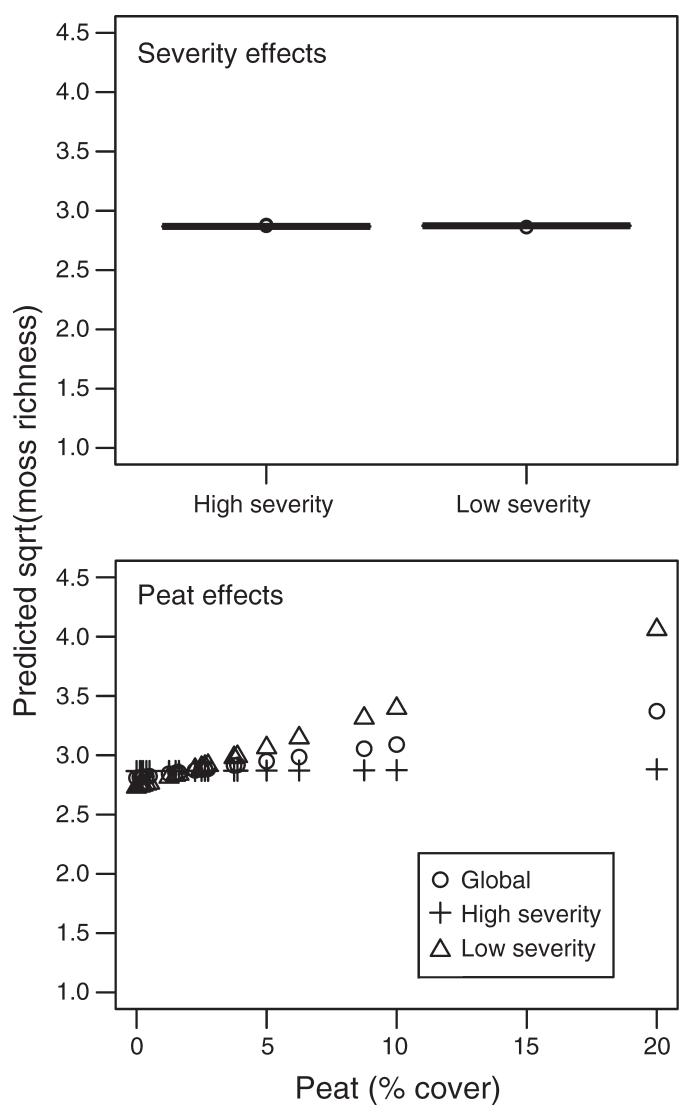

FIG. 5. Relationships between fire severity and peat abundance and predicted moss richness. See Fig. 4 for details. 

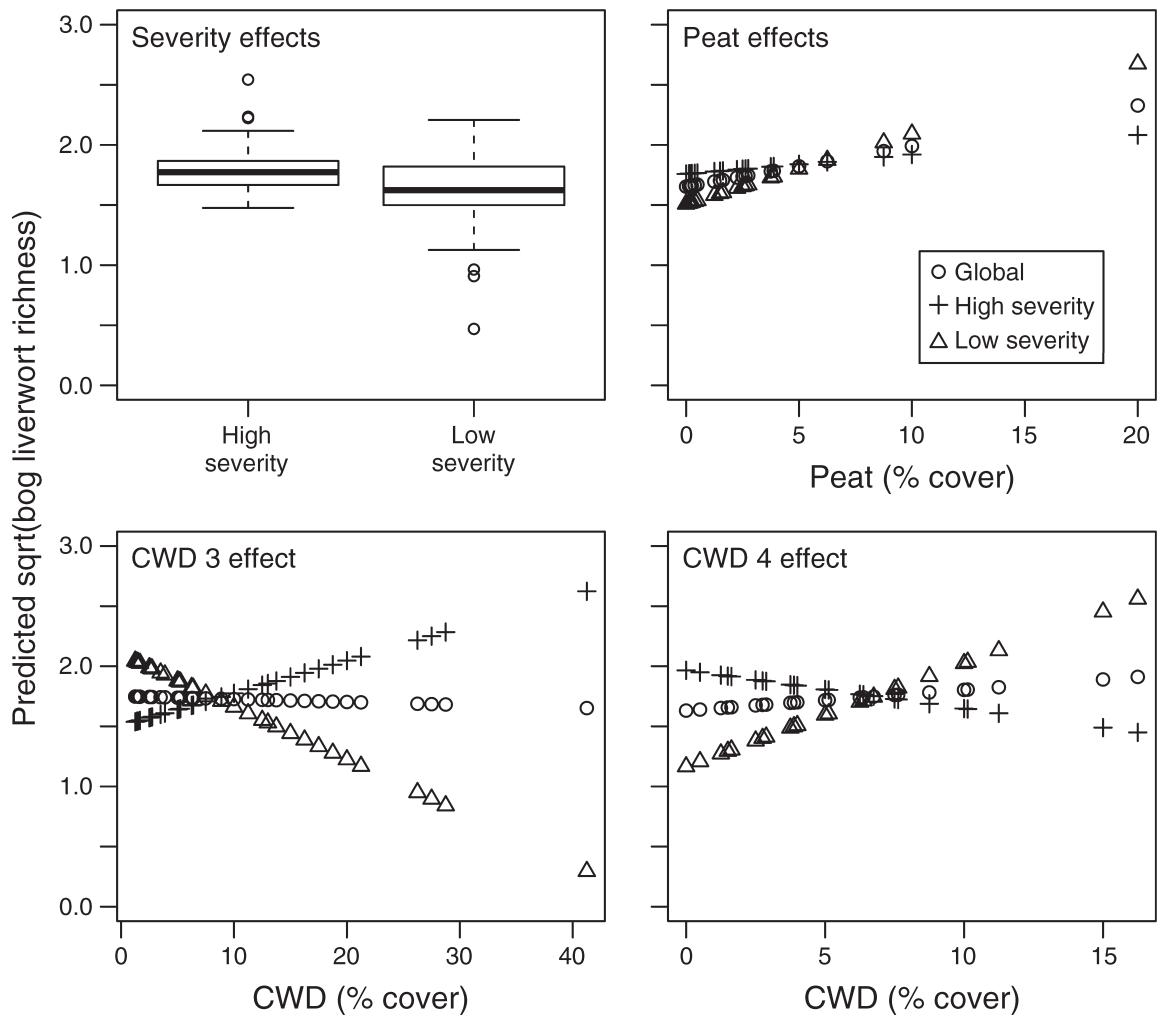

FIG. 6. Relationships between fire severity, peat abundance, CWD3 and CWD4 abundance, and predicted bog liverwort richness. See Fig. 4 for details..

the Lake Abitibi Model Forest, and by an NSERC partnership grant with Forest Industries and the Canadian Forest Service.

\section{Literature Cited}

Bauhus, J., K. Puettmann, and C. Messier. 2009. Silviculture for old-growth attributes. Forest Ecology and Management 258:525-537.

Belleau, A., A. Leduc, N. Lecomte, and Y. Bergeron. 2011. Forest succession rate and pathways on different surface deposit types in the boreal forest of northwestern Quebec. Ecoscience 18:329-340.

Benscoter, B. W. 2006. Post-fire bryophyte establishment in a continental bog. Journal of Vegetation Science 17:647-652.

Benscoter, B. W., and D. H. Vitt. 2008. Spatial patterns and temporal trajectories of the bog ground layer along a postfire chronosequence. Ecosystems 11:1054-1064.

Benscoter, B. W., and R. K. Wieder. 2003. Variability in organic matter lost by combustion in a boreal bog during the 2001 Chisholm fire. Canadian Journal of Forest Research 33: 2509-2513.

Benscoter, B. W., R. K. Wieder, and D. H. Vitt. 2005. Linking microtopography with post-fire succession in bogs. Journal of Vegetation Science 16:453-460.

Bergeron, Y., S. Gauthier, M. Flannigan, and V. Kafka. 2004. Fire regimes at the transition between mixedwood and coniferous boreal forest in northwestern Quebec. Ecology 85:1916-1932.

Black, R. A., and L. C. Bliss. 1978. Recovery sequence of Picea mariana-Vaccinium uliginosum forests after burning near Inuvik, Northwest Territories, Canada. Canadian Journal of Botany 56:2020-2030.

Borcard, D., F. Gillet, and P. Legendre. 2011. Numerical ecology with R. Springer, New York, New York, USA.
Browning, B. J., G. J. Jordan, P. J. Dalton, S. J. Grove, T. J. Wardlaw, and P. A. M. Turner. 2010. Succession of mosses, liverworts and ferns on coarse woody debris, in relation to forest age and log decay in Tasmanian wet eucalypt forest. Forest Ecology and Management 260:1896-1905.

Buck, W. R., and B. Goffinet. 2000. Morphology and classification of mosses. Pages 71-123 in B. A. J. G. Shaw, editor. Bryophyte biology. Cambridge University Press, Cambridge, UK.

Burnham, K. P., and D. R. Anderson. 2002. Model selection and multimodel inference: a practical information-theoretic approach. Springer, New York, New York, USA.

Campetella, G., Z. Botta-Dukat, C. Wellstein, R. Canullo, S. Gatto, S. Chelli, L. Mucina, and S. Bartha. 2011. Patterns of plant trait-environment relationships along a forest succession chronosequence. Agriculture, Ecosystems and Environment 145:38-48.

Clymo, R. S., and J. Duckett. 1986. Regeneration of Sphagnum. New Phytologist 102:589-614.

Cronberg, N. 2002. Colonization dynamics of the clonal moss Hylocomium splendens on islands in a Baltic land uplift area: reproduction, genet distribution and genetic variation. Journal of Ecology 90:925-935.

Crum, H., and L. E. Anderson. 1981. The mosses of eastern North America. Columbia University Press, New York, New York, USA.

Cyr, D., Y. Bergeron, S. Gauthier, and A. C. Larouche. 2005. Are the old-growth forests of the Clay Belt part of a fireregulated mosaic? Canadian Journal of Forest Research 35: $65-73$.

De'ath, G. 2002. Multivariate regression trees: a new technique for modeling species-environment relationships. Ecology 83: 1105-1117. 
de Chantal, M., S. Lilja-Rothsten, C. Peterson, T. Kuuluvainen, I. Vanha-Majamaa, and P. Puttonen. 2009. Tree regeneration before and after restoration treatments in managed boreal Picea abies stands. Applied Vegetation Science 12:131-143.

DeGrandpré, L., D. Gagnon, and Y. Bergeron. 1993. Changes in the understory of Canadian southern boreal forest after fire. Journal of Vegetation Science 4:803-810.

During, H. J. 1992. Ecological classification of bryophytes and lichens. Pages 1-31 in J. Bates and A. Farmer, editors. Bryophytes and lichens in a changing environment. Clarendon Press, Oxford, UK.

Dynesius, M., H. Gibb, and J. Hjältén. 2010. Surface covering of downed logs: drivers of a neglected process in dead wood ecology. PLoS One 5(10):e13237.

Ellis, C. J., and S. C. Ellis. 2010. Quantifying the role of deterministic assembly and stochastic drift in a natural community of Arctic mosses. Oikos 119:465-474.

Evans, S. A., C. B. Halpern, and D. McKenzie. 2012. The contributions of forest structure and substrate to bryophyte diversity and abundance in mature coniferous forests of the Pacific Northwest. Bryologist 115:278-294.

Fastie, C. L. 1995. Causes and ecosystem consequences of multiple pathways of primary succession at Glacier Bay, Alaska. Ecology 76:1899-1916.

Fenton, N. J., and Y. Bergeron. 2006. Facilitative succession in a boreal bryophyte community driven by changes in available moisture and light. Journal of Vegetation Science 17:65-76.

Fenton, N. J., and Y. Bergeron. 2008. Does time or habitat make old-growth forests species rich? Bryophyte richness in boreal Picea mariana forests. Biological Conservation 141: 1389-1399.

Fenton, N. J., K. A. Frego, and M. Sims. 2003. Changes in forest floor bryophyte (moss and liverwort) communities 4 years after forest harvest. Canadian Journal of Botany 81: 714-731.

Foster, D. R. 1985. Vegetation development following fire in Picea mariana (black spruce)-Pleurozium forests of southeastern Labrador, Canada. Journal of Ecology 73:517-534.

Foster, D. R., D. H. Knight, and J. F. Franklin. 1998. Landscape patterns and legacies resulting from large, infrequent forest disturbances. Ecosystems 1:497-510.

Frego, K. A. 1996. Regeneration of four boreal bryophytes: colonization of experimental gaps by naturally occuring propagules. Canadian Journal of Botany 74:1937-1942.

Frisvoll, A. A. 1997. Bryophytes of spruce forest stands in Central Norway. Lindbergia 22:83-97.

Fukami, T., T. M. Bezemer, S. R. Mortimer, and W. H. van der Putten. 2005. Species divergence and trait convergence in experimental plant community assembly. Ecology Letters 8: 1283-1290.

Fukami, T., I. A. Dickie, J. P. Wilkie, B. C. Paulus, D. Park, A. Roberts, P. K. Buchanan, and R. B. Allen. 2010. Assembly history dictates ecosystem functioning: evidence from wood decomposer communities. Ecology Letters 13:675-684.

Gignac, L. D. 1992. Niche structure, resource partitioning and species interactions of mire bryophytes relative to climatic and ecological gradients in western Canada. Bryologist 95: $406-418$.

Götzenberger, L., et al. 2012. Ecological assembly rules in plant communities - approaches, patterns and prospects. Biological Reviews 87:111-127.

Greene, D. F., et al. 2007. The reduction of organic-layer depth by wildfire in the North American boreal forest and its effect on tree recruitment by seed. Canadian Journal of Forest Research 37:1012-1023.

Harper, K. A., Y. Bergeron, P. Drapeau, S. Gauthier, and L. DeGrandpré. 2005. Structural development following fire in black spruce boreal forest. Forest Ecology and Management 206:293-306.
Heinselman, M. 1963. Fire sites, bog processes and peatland types in the glacial Lake Agassiz region, Minnesota. Ecological Monographs 33:327-374.

Herben, T. 1995. Founder and dominance control: neglected concepts in the community dynamics of clonal plants. Abstracta Botanica 19:3-10.

Hubbell, S. P. 2001. The unified neutral theory of biodiversity and biogeography. Princeton University Press, Princeton, New Jersey, USA.

Huntley, B., et al. 2010. Beyond bioclimatic envelopes: dynamic species' range and abundance modelling in the context of climatic change. Ecography 33:621-626.

Hutchinson, G. E. 1959. Homage to Santa Rosalia or why are there so many kinds of animals? American Naturalist 93:145159.

Hylander, K., and S. Johnson. 2010. In situ survival of forest bryophytes in small-scale refugia after an intense forest fire. Journal of Vegetation Science 21:1099-1109.

Inouye, R. S., and D. Tilman. 1995. Convergence and divergence of old-field vegetation after $11 \mathrm{yr}$ of nitrogen addition. Ecology 76:1872-1887.

Johnson, E. A. 1992. Fire and vegetation dynamics: studies from the North American boreal forest. Cambridge University Press, Cambridge, UK.

Jonsson, B. G., and P. Esseen. 1998. Plant colonisation in small forest-floor patches: importance of plant group and disturbance traits. Ecography 21:518-526.

Kouki, J., E. Hyvarinen, H. Lappalainen, P. Martikainen, and M. Simila. 2012. Landscape context affects the success of habitat restoration: large-scale colonization patterns of saproxylic and fire-associated species in boreal forests. Diversity and Distributions 18:348-355.

Laaka-Lindberg, S., H. Korpelainen, and M. Pohjamo. 2006. Spatial distribution of epixylic hepatics in relation to substrate in a boreal old-growth forest. Journal of the Hattori Botanical Library 100:311-323.

Larsen, D. R., and P. L. Speckman. 2004. Multivariate regression trees for analysis of abundance data. Biometrics 60:543-549.

Lecomte, N., M. Simard, and Y. Bergeron. 2006. Effects of fire severity and initial tree composition on stand structural development in the coniferous boreal forest of northwestern Quebec, Canada. Ecoscience 13:152-163.

Lecomte, N., M. Simard, Y. Bergeron, A. Larouche, H. Asnong, and P. Richard. 2005. Effects of fire severity and initial tree composition on understory vegetation dynamics in a boreal landscape inferred from chronosequence and paleoecological data. Journal of Vegetation Science 16:665674.

Lee, P., and K. Sturgess. 2001. The effects of logs, stumps, and root throws on understory communities within 28-year-old aspen-dominated boreal forests. Canadian Journal of Botany 79:905-916.

Lepš, J., and M. Rejmanek. 1991. Convergence or divergence: What should we expect from vegetation succession? Oikos 62: 261-264.

Ley, L. M., and J. M. Crowe. 1999. An enthusiast's guide to the liverworts and hornworts of Ontario. Lakehead University, Thunder Bay, Ontario, Canada.

Lõhmus, A., and P. Lõhmus. 2008. First-generation forests are not necessarily worse than long-term managed forests for lichens and bryophytes. Restoration Ecology 16:231-239.

Madžule, L., G. Brumelis, and D. Tjarve. 2012. Structures determining bryophyte species richness in a managed forest landscape in boreo-nemoral Europe. Biodiversity and Conservation 21:437-450.

Mazerolle, M. J. 2006. Improving data analysis in herpetology: using Akaike's Information Criterion (AIC) to assess the strength of biological hypotheses. Amphibia-Reptilia 27:129180 . 
Mazerolle, M. J. 2012. Package "AICcmodavg. Model selection and multimodel inference based on (Q)AIC (c) version 1.24. R Foundation for Statistical Computing, Vienna, Austria.

McCune, B., and T. F. H. Allen. 1985. Will similar forests develop on similar sites? Canadian Journal of Botany 63:367376.

Mills, S. E., and E. MacDonald. 2005. Factors influencing bryophyte assemblage at different scales in the western Canadian boreal forest. Bryologist 108:86-100.

Økland, R. H. 1990. A phytoecological study of the mire Norther Kisselbergmosen, SE Norway. III. Diversity and habitat niche relationships. Nordic Journal of Botany 10: 191-220.

Økland, R. H., K. Rydgren, and T. Økland. 2003. Plant species composition of boreal spruce swamp forests: closed doors and windows of opportunity. Ecology 84:1909-1919.

Payette, S. 1992. Fire as a controlling process in the North American boreal forest. Pages 144-169 in H. H. Shugart, R. Leemans, and G. B. Bonan, editors. A systems analysis of the global boreal forest. Cambridge University Press, New York, New York, USA.

Pharo, E. J., and D. B. Lindenmayer. 2009. Biological legacies soften pine plantation effects for bryophytes. Biodiversity and Conservation 18:1751-1764.

Pharo, E. J., and D. H. Vitt. 2000. Local variation in bryophyte and macro-lichen cover and diversity in montane forests of western Canada. Bryologist 103:455-466.

Pinheiro, J. C., and D. M. Bates. 2000. Mixed-effects models in S and S-PLUS. Springer, New York, New York, USA.

R Development Core Team. 2012. R: a language and environment for statistical computing. R Foundation for Statistical Computing, Vienna, Austria.

Robert, E., L. Rochefort, and M. Garneau. 1999. Natural revegetation of two block-cut mined peatlands in eastern Canada. Canadian Journal of Botany 77:447-459.

Rowe, J. S. 1983. Concepts of fire effects on plant individuals and species. Pages 135-154 in R. W. Wein and D. A. MacLean, editors. The role of fire in northern circumpolar ecosystems. John Wiley and Sons, Chichester, UK.

Rydgren, K., G. Hestmark, and R. Økland. 1998. Revegetation following experimental disturbance in a boreal old-growth Picea abies forest. Journal of Vegetation Science 9:763-776.

Rydin, H. 1997. Competition among bryophytes. Advances in Bryology 6:135-168.

Samuels, C. L., and J. A. Drake. 1997. Divergent perspectives on community convergence. Trends in Ecology and Evolution 12:427-432.

Schimmel, J., and A. Granström. 1996. Fire severity and vegetation response in the boreal Swedish forest. Ecology 77: $1436-1450$.
Schmalholz, M., K. Hylander, and K. Frego. 2011. Bryophyte species richness and composition in young forests regenerated after clear-cut logging versus after wildfire and spruce budworm outbreak. Biodiversity and Conservation 20:25752596.

Shafi, M. I., and G. A. Yarranton. 1973. Vegetational heterogeneity during a secondary (postfire) succession. Canadian Journal of Botany 51:73-90.

Shetler, G., M. R. Turetsky, E. Kane, and E. Kasischke. 2008. Sphagnum mosses limit total carbon consumption during fire in Alaskan black spruce forests. Canadian Journal of Forest Research 38:2328-2336.

Simard, M., N. Lecomte, Y. Bergeron, P. Y. Bernier, and D. Paré. 2007. Forest productivity decline caused by successional paludification of boreal soils. Ecological Applications 17: $1619-1637$.

Slack, N. 1990. Bryophytes and ecological niche theory. Botanical Journal of the Linnean Society 104:187-213.

Söderström, L. 1987. Dispersal as a limiting factor for distribution among epixylic bryophytes. Symposia Biologica Hungarica 35:475-483.

Söderström, L. 1988. The occurrence of epixylic bryophyte and lichen species in an old natural and a managed forest stand in northeast Sweden. Biological Conservation 45:169-178.

Söderström, L., and T. Herben. 1997. Dynamics of bryophyte metapopulations. Advances in Bryology 6:205-240.

Taylor, A. R., and H. Y. H. Chen. 2011. Multiple successional pathways of boreal forest stands in central Canada. Ecography 34:208-219.

Taylor, S. J., T. J. Carleton, and P. Adams. 1987. Understory vegetation change in a Picea mariana chronosequence. Vegetatio 73:63-72.

ter Braak, C., and P. Šmilauer. 1998. CANOCO for Windows version 4.2. Centre for Biometry Wagenin, CPRO-DLO, Wageningen, The Netherlands.

Toivanen, T., and J. S. Kotiaho. 2010. The preferences of saproxylic beetle species for different dead wood types created in forest restoration treatments. Canadian Journal of Forest Research 40:445-464.

Trowbridge, W. B. 2007. The role of stochasticity and priority effects in floodplain restoration. Ecological Applications 17: $1312-1324$

Turetsky, M. R., B. Bond-Lamberty, E. Euskirchen, J. Talbot, S. Frolking, A. D. McGuire, and E.-S. Tuittila. 2012. The resilience and functional role of moss in boreal and arctic ecosystems. New Phytologist 196:49-67.

Turner, M. G., W. H. Romme, and D. B. Tinker. 2003. Surprises and lessons from the 1988 Yellowstone fires. Frontiers in Ecology and the Environment 1:351-358.

\section{Supplemental Material}

Appendix A

Convergent succession in habitat variables (Ecological Archives E094-182-A1).

\section{Appendix B}

Species classifications by guild (Ecological Archives E094-182-A2). 